\title{
Skill-Upgrading and Internationalization Country-of-Origin or End-Use of Products
}

\author{
Sørensen, Anders
}

Document Version

Final published version

Publication date:

2007

\section{License \\ CC BY-NC-ND}

Citation for published version (APA):

Sørensen, A. (2007). Skill-Upgrading and Internationalization: Country-of-Origin or End-Use of Products. Centre for Economic and Business Research, Copenhagen Business School.

Link to publication in CBS Research Portal

\section{General rights}

Copyright and moral rights for the publications made accessible in the public portal are retained by the authors and/or other copyright owners and it is a condition of accessing publications that users recognise and abide by the legal requirements associated with these rights.

\section{Take down policy}

If you believe that this document breaches copyright please contact us (research.lib@cbs.dk) providing details, and we will remove access to the work immediately and investigate your claim. 


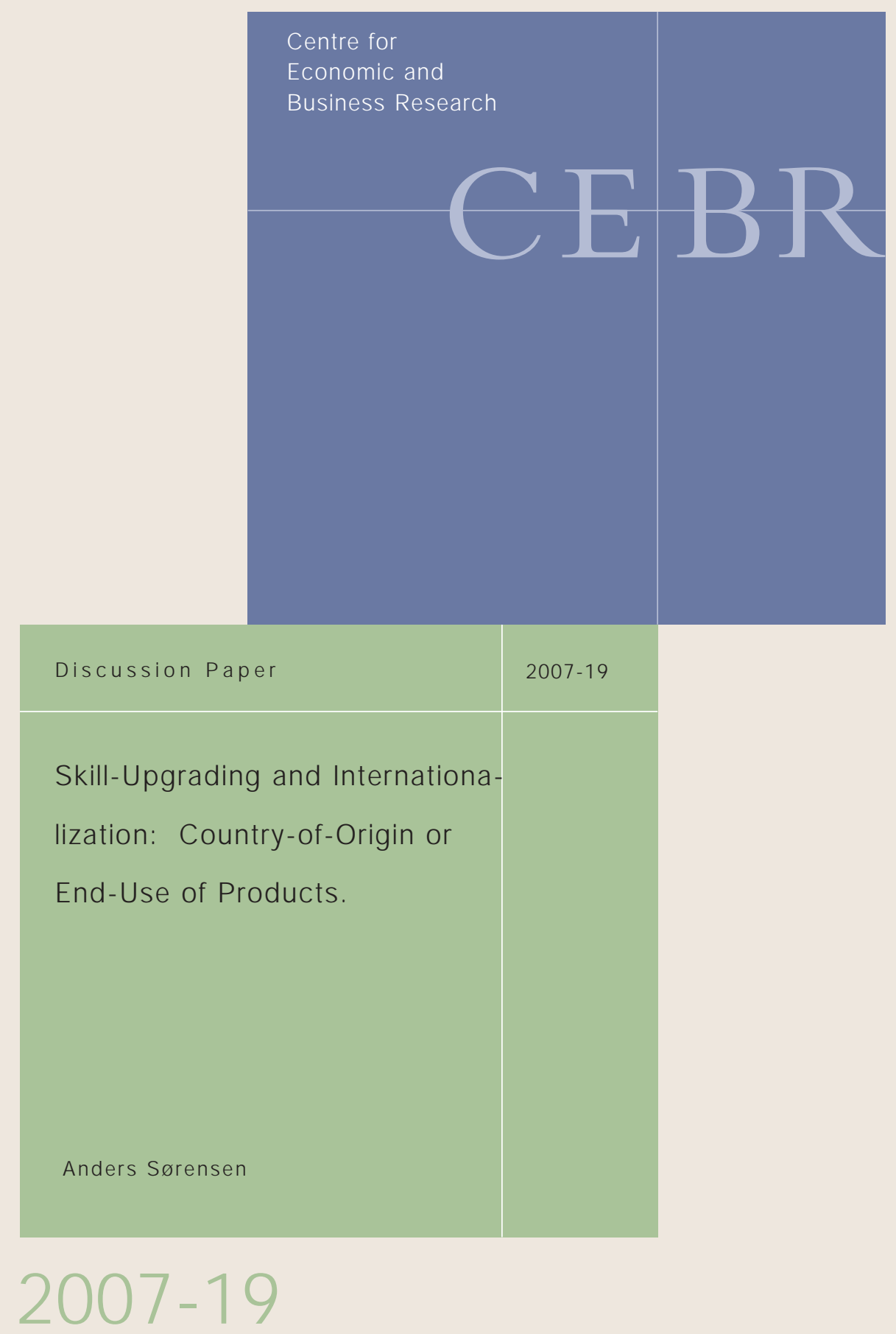




\title{
Skill-Upgrading and Internationalization: Country-of-Origin or End-Use of Products*
}

\author{
Anders Sørensen
}

August 2007

\begin{abstract}
This paper investigates the empirical consequences for the relationship between skill upgrading and internationalization by decomposing import after country-of-origin and after the end-use of products. I find that the break-down after country-of-origin is of crucial importance, implying that international trade with low-wage countries leads to comprehensive skill upgrading, whereas international trade with high-wage countries leads to skill downgrading in Danish Manufacturing. The empirical literature on skill-upgrading and internationalization has mainly focused on international outsourcing and has to a large extent disregarded import penetration. By splitting import after country-of-origin, this reintroduces import penetration as an important explanation for skill upgrading.
\end{abstract}

Keywords: skill upgrading, import, country-of-origin, end-use of products

*I am grateful to Mikael Bjørk Andersen for outstanding research assistance; and to the Tuborg Foundation for financial support. The usual disclaimer applies. Address: Department of Economics, Copenhagen Business School and Centre for Economic and Business Research (CEBR), Porcelænshaven 16A, DK-2000 Frederiksberg, Denmark. 


\section{Introduction}

This paper investigates the empirical consequences for the relationship between skill upgrading and internationalization by decomposing import after countryof-origin - low-wage and high-wage countries - and after end-use of products intermediate inputs and final goods. The main result is that the break-down after country-of-origin is of crucial importance. It is found that international trade with low-wage countries leads to comprehensive skill upgrading, whereas international trade with high-wage countries leads to skill downgrading. The latter result suggests that Danish manufacturing for which the study is carried out, has comparative advantages in processes that use skilled labor intensively when compared to low-wage countries and comparative advantages in processes that use unskilled labor intensively when compared to high-wage countries.

Skill upgrading is measured by the change in cost share of skill types and internationalization is measured by different components of import; international outsourcing and import penetration broken-down after country-of-origin. The study is based on a unique data set of international trade. The data set enables me to focus on where imports originate rather than on their overall level.

An important aspect of foreign competition in product markets is that it pressures domestic firms out of business or make them change the product mix. A recent study by Bernard, Jensen and Schott (2006) finds support for import penetration from low-wage countries to play an important role for firms to adjust their product mix in order to avoid trade pressures. This suggests that industries shift towards more skill intensive activities as a consequence of increasing international competition in product markets from low-wage countries and that this shift may take place within industries. ${ }^{1}$ I study the relationship between the composition of skills and import penetration broken down by country-of-origin.

This hypothesis has not been investigated in the literature. Instead the hypothesis that industries shift towards more skill intensive activities as a

\footnotetext{
${ }^{1}$ Bernard, Jensen, and Schott (2006) investigate the relationship between skill-upgrading and import penetration from low-wage countries but find no statistically significant evidence. However, they measure skill-mix using non-production workers and production workers, which is not necessarily a good measure for the skill-distribution because the correlation between educational level and production/non-production is low, see Doms, Dunne, and Troske (1997). In this paper, I use wage shares of educational groups to measure the skill mix.
} 
consequence of increasing international competition in product markets from all countries have been studied. There has only been weak support for the verification for this hypothesis. See for example, Autor, Katz, and Krueger (1998).

The claim that import penetration is without importance is also based on shift-share analyses. Using this method it is found that within-industry effects dominate skill-upgrading, whereas between-industry effects are modest. The interpretation is that import penetration is without importance for skill upgrading, because trade according to this view affects composition of skills through a changing industry structures, see for example Berman, Bound and Griliches (1994).

However, the view that import penetration potentially affect the composition of skills through a changing industry structures is valid as long as products within single industries are homogeneous. If they to a larger extent are heterogenous there are, however, room for firms to adjust the product-mix towards skill-intensive production without switching industry.

\section{The Empirical Model}

The empirical specification follows Feenstra (2004):

$$
\Delta s_{j, t}=\alpha_{0}+\beta_{1} \Delta \ln \left(k_{j, t}\right)+\beta_{2} \Delta \ln \left(y_{j, t}\right)+\beta_{s}^{\prime} \Delta z_{j, t}+\varepsilon_{j, t}
$$

where $s_{j, t}$ is the cost share of skilled labor to total labor costs in industry $j$ observed at time $t, y_{j, t}$ is production in firm $i, k_{j, t}$ is the capital stock of firm $i, z_{j, t}$ denotes the vector of structural variables that shift costs, and $\varepsilon_{j, t}$ is a shock to skill-upgrading. The shift parameters are composed of measures of internationalization and technology. Below, I describe the applied measures.

\subsection{Measures of International Trade}

The applied measures of internationalization are measures of international outsourcing and import penetration. These measures are further decomposed after low- and high-wage countries. 
I apply a narrow, a broad, and a difference measure of international outsourcing as developed by Feenstra and Hanson (1999). The three measures for industry $j$ are:

$$
\begin{aligned}
o_{j}^{\text {narrow }} & =\frac{M_{j, j}^{\text {input }}}{Y_{j}} \\
o_{j}^{\text {broad }} & =\frac{\sum_{i} M_{i, j}^{\text {input }}}{Y_{j}}
\end{aligned}
$$

and $o_{j}^{\text {difference }}=o_{j}^{\text {broad }}-o_{j}^{\text {narrow }} . o_{j}$ denotes international outsourcing. $M_{i, j}^{\text {input }}$ denotes import of intermediate input from foreign industry $i$ to domestic industry $j$, and $Y_{j}$ denotes production of industry $j$. 'narrow' and 'broad' refer to the narrow and broad measure of international outsourcing.

The measure of import penetration follows the measure applied by Bernard and Jensen (2006):

$$
P E N_{j}=\frac{M_{j}^{\mathrm{FG}}}{Y_{j}}+\frac{\sum_{i} M_{j, i}^{\mathrm{input}}}{Y_{j}}
$$

where $P E N_{j}$ is the import penetration in industry $j$ and $M_{j}^{\mathrm{FG}}$ denotes denotes import of final goods from foreign industry $j$. It is clear from the measure that import penetration can be decomposed after intermediate inputs and final goods.

The measures of external trade are decomposed after low- and high-wage countries, i.e.,

$$
\begin{aligned}
P E N_{j} & =L W P E N_{j}+H W P E N_{j} \\
o_{j} & =L W o_{j}+H W o_{j}
\end{aligned}
$$

Finally, I use R\&D intensities as shift variable for the technological level.

\section{Data}

The above mentioned trade measures are constructed for 53 manufacturing industries for the years 1995 and 2000. Moreover, the measures are divided after low- and high-wage countries. 
The trade data for the Danish economy are unique because it is possible to distinguish import in two dimensions; country-of-origin and end-use of products. The main source is the input-output tables from Statistics Denmark. The input-output tables comprise information on imported intermediate input from foreign industry $i$ to domestic industry $j$ and import of final products to private and government consumption, investments, export and supply inventories. In the standard input-output tables, import is not subdivided into country-of-origin.

The construction of input-output tables is based on so-called supply-anduse tables. These tables are based on around 2,750 product accounts. Each product account contains information on the supply of a product (domestic production after industry, import and supply of investment goods) and the use of a product (intermediate input, consumption, export, and supply inventories). To distinguish a product by country-of-origin, import and export for the product is combined with the country distribution of import and export for the relevant product from the external trade statistics. After having divided external trade after country-of-origin for all product accounts, the input-output table with external trade divided after country-of-origin are constructed using the standard method for constructing input-output tables, see Statistics Denmark (1986).

\section{Empirical Results.}

Table 1 presents results using different specifications of internationalization going from aggregate to disaggregate measures of internationalization. The first three regressions present the results for skill upgrading and internationalization when relatively aggregate measures are applied. Regressions (1) and (2) show the results when aggregate measures of internationalization, i.e., $o_{j}^{\text {broad }}$ and $P E N_{j}$ aggregated and separately. The important observation is that internationalization in general has no impact on skill upgrading.

This result is changed when measures of internationalization are brokendown after country-of-origin. The result is presented in Regression (3). In this case, it is clear that increasing trade with low-wage countries leads to skill upgrading, whereas increasing trade with high-wage countries leads to skill downgrading. 
In the next three regressions refine Regression (3) by decomposing measures of internationalization further after end-use of imports. In Regression (4) broad measures of international outsourcing and measures of import penetration are applied. Surprisingly it is found that international outsourcing has no significant effect on skill upgrading, whereas import penetration has.

It is evident that this division is of crucial importance, since measures of import penetration enter highly significant. Skill-upgrading is more pronounced in industries with extensive import penetration from low-wage countries. On the contrary, skill-downgrading is pronounced in industries with extensive import penetration from high-wage countries.

In Regressions (5), (6), and (7) measures of internationalization are refined further. In Regression (5), the narrow and the difference measure of international outsourcing is applied, whereas import penetration is decomposed after intermediate input and final goods in Regression (6). Regression (7) applies both decompositions. In all cases the conclusion established by Regression (4) is robust.

The main finding suggests that it is of crucial importance to distinguish imports by country-of-origin. I find that international trade measured at the industry level from low-wage countries leads to skill upgrading. I also find that import penetration from high-wage countries leads to skill downgrading. The results suggest that Danish manufacturing firms have comparative advantage in skill-intensive production when compared to low-wage countries and comparative advantage in production processes intensive in unskilled labor when compared to other high-wage countries. The importance of decomposing import penetration after country of origin is emphasized by the result that overall import penetration has no effect significant effect on skill-upgrading.

Surprisingly, international outsourcing is without importance for skill-upgrading. In Regressions (5) and (7), I decompose broad measure of international outsourcing into the narrow measure and the difference measure; again decomposed after country-of-origin. Still, the measures of international outsourcing do not contribute to explaining skill-upgrading.

Based on the parameter estimates of Regression (6), I find that import penetration from low-wage countries on average contributes 32 percent of skillupgrading, whereas import penetration from high-wage countries contributes 
-16 percent, i.e., skill-downgrading. In total the net-contribution from import penetration is around $1 / 6$ of skill-upgrading.

\section{Discussion and Conclusion}

This paper suggests that import from low-wage countries important for skillupgrading, whereas import from high-wage countries leads to skill-downgrading. There are two broader implications of this result. First, measures of internationalization should be broken-down after country-of-origin when skillupgrading is studied and probably also other issues related to internationalization. Second, measures of import penetration should be reintroduced when studying skill-upgrading.

The applied measure of international outsourcing is found to be with significant importance for skill-upgrading in the present case for Danish manufacturing. The potential reason for this is that the applied measures of international outsourcing containing a number of potential measurement problems. The standard measures are usually based on data from input-output tables that are problematic since they exclude international outsourcing of the final stage of production besides that there are usually not distinction between countryof-origin ${ }^{2}$. E.g., assembly is an activity where many low-wage countries have their comparative advantage, see Ng and Yeats (1999); an activity not included in standard measures of international outsourcing. For this reason, it cannot be concluded that international outsourcing is without importance.

\footnotetext{
${ }^{2}$ Ekholm and Hakkala (2006), and Hijzen, Görg and Hine (2005) also break international oursourcing down after country-of-origin.
} 


\section{References}

[1] Autor, D.H., L.F. Katz, and A.B. Krueger (1998): "Computing Inequality: Have Computers Changed the Labor Market?" Quarterly Journal of Economics, 113 (4), 1169-1213.

[2] Berman, E., J. Bound and Z. Griliches (1994): "Changes in the Demand for Skilled Labor within U.S. Manufacturing: Evidence from the Annual Survey of Manufactures," Quarterly Journal of Economics, 109(2), 367398.

[3] Berman, E., J. Bound, and S. Machin (1998): "Implications of SkillBiased Technical Changes: International Evidence," Quarterly Journal of Economics, 113(4), 1245-1280.

[4] Doms, M., T. Dunne, K.R. Troske (1997): "Workers, Wages, and Technology," Quarterly Journal of Economics, 112(1), 253-90

[5] Ekholm, K., and K. Hakkala (2006), "The Effect of Offshoring on Labor Demand: Evidence from Sweden", CEPR working paper \#5648

[6] Feenstra, R.D. and G.D. Hanson (1996), "Globalization, Outsourcing, and Wage Inequality", American Economic Review, 86(2), Papers and Proceedings, 240-245

[7] Feenstra, R.D. and G.D. Hanson (1999), "The Impact of Outsourcing and High-Technology Capital on Wages: Estimates for the United States, 1979-1990", Quarterly Journal of Economics, 114, 907-41

[8] Feenstra, R.C. and G.D. Hanson (2003): "Global Production Sharing and Rising Inequality: A Survey of Trade and Wages," in Kwan Choi and James Harrigan (eds.): "Handbook of International Trade," Basil Blackwell.

[9] Hijzen, Görg and Hine (2005), "International Outsourcing and the Skill Structure of Labor Demand in the United Kingdom", Economic Journal, $115,506,860-878$

[10] Katz, L.F. and K.M. Murphy (1992): "Changes in Relative Wages, 19631987: Supply and Demand Factors," Quarterly Journal of Economics, 107(1), 35-78. 
[11] Machin, S., and J. Van Reenen (1998): "Technology and Changes in Skill Structure: Evidence from Seven OECD Countries," Quarterly Journal of Economics, 113(4), 1215-1244.

[12] Ng and Yeats (1999), "Production Sharing in East Asia - Who Does What for Whom and Why?", Policy Research Working Paper 2197, World Bank

[13] Statistics Denmark (1986), "Commodity Flow Systems and Construction of Input-Output Tables in Denmark", Arbejdspapir nr. 15 
Table 1: Change in Skilled Labor Wage Share, 1995-2000, as Dependent Variable

\begin{tabular}{|c|c|c|c|c|c|c|c|c|c|}
\hline & & & $(1)$ & $(2)$ & (3) & $(4)$ & $(5)$ & $(6)$ & $(7)$ \\
\hline $\mathrm{dlnK} / \mathrm{Y}$ & & & & -0.023 & 0.021 & -0.012 & 0.000 & -0.010 & 0.001 \\
\hline $\mathrm{dln} Y$ & & & & -0.001 & -0.006 & 0.010 & 0.013 & 0.006 & 0.010 \\
\hline \multirow[t]{6}{*}{ Outsourcing } & Low-wage & Narrow & \multirow{10}{*}{-0.021} & \multirow{6}{*}{-0.085} & & \multirow[b]{3}{*}{-0.510} & & & \\
\hline & & & & & & & 0.448 & -0.493 & 0.296 \\
\hline & & Broad-narrow & & & & & -1.062 & & -0.943 \\
\hline & High-wage & Narrow & & & & ת ח & & O 07 & \\
\hline & & & & & & -0.070 & -0.210 & ו & -0.168 \\
\hline & & Broad-narrow & & & & & -0.062 & & -0.081 \\
\hline \multirow[t]{4}{*}{ Import penetration } & Low-wage & Intermediate & & \multirow{4}{*}{-0.019} & \multirow[b]{2}{*}{$0.148 * *$} & \multirow[b]{2}{*}{$0.168 * * *$} & \multirow[b]{2}{*}{$0.151^{* * *}$} & $0.446 * * *$ & $0.393 * * *$ \\
\hline & & Final & & & & & & $0.162 * * *$ & $0.141 * * *$ \\
\hline & High-wage & Intermediate & & & \multirow[b]{2}{*}{$-0.056^{* * *}$} & \multirow[b]{2}{*}{$-0.051^{* * *}$} & \multirow[b]{2}{*}{$-0.049 * * *$} & $-0.048 * * *$ & $-0.049 * * *$ \\
\hline & & Final & & & & & & $-0.094 * * *$ & $-0.075 * *$ \\
\hline $\mathrm{R} \& \mathrm{D}$ & & & -0.010 & -0.047 & 0.382 & 0.382 & $0.611^{* *}$ & 0.319 & 0.522 \\
\hline $\mathrm{R} 2$ & & & 0.084 & 0.091 & 0.339 & 0.375 & 0.467 & 0.452 & 0.491 \\
\hline $\mathrm{n}$ & & & 53 & 53 & 53 & 53 & 53 & 53 & 53 \\
\hline
\end{tabular}

Note: All regressions are computed over 53 NACE-industries and are weighted by the average industry share of the manufacturing wage bill using

White Heteroscedasticity consistent standard errors. ***1\% confidence level, **5\% confidence level, and *10\% confidence level.

Sources: Statistics Danmark and OECD ANBERD Database. 